\title{
RESEARCH PAPER \\ Characterization of resistance expression in genotypes of Solanum Section Lycopersicon against Tuta absoluta (Lepidoptera: Gelechiidae)
}

\author{
Nancy Vitta ${ }^{1}$, Patricia Estay ${ }^{1}$, and Rodrigo A. Chorbadjian ${ }^{2}$ \\ ${ }^{1}$ Instituto de Investigaciones Agropecuarias INIA, Centro Regional de Investigación La Platina, Casilla \\ 439-3, Santiago, Chile. \\ ${ }^{2}$ Pontificia Universidad Católica de Chile, Facultad de Agronomía e Ingeniería Forestal, Departamento de \\ Ciencias Vegetales, Casilla 306-22, Santiago, Chile.
}

\begin{abstract}
N. Vitta, P. Estay, and Chorbadjian, R.A. 2016. Characterization of resistance expression in genotypes of Solanum Section Lycopersicon against Tuta absoluta (Lepidoptera: Gelechiidae). Cien. Inv. Agr. 43(3):366-373. Two studies were conducted with the aim of characterizing the antixenosis and antibiosis resistance expression of genotypes in the Solanum section Lycopersicon against Tuta absoluta (Meyrick). The species used were $S$. lycopersicum (Fiorentino, Naomi and Belle), S. habrochaites (RCAT030597, PI126446), S. chilense (INIABB79), S. peruvianum (RCAT031296, RCAT039874 and RCAT030403) and $S$. pimpinellifolium (PI390739). For the antixenosis bioassay, a leaf was removed from plants of each genotype and placed in a cup with a floral foam soaked in water. The cups were stored in cages covered with anti-aphid mesh. The number of eggs per plant was determined seven days after releasing the adults. For the antibiosis bioassay, one leaf per genotype and replication was placed in a plastic cup with floral foam soaked in water, and first-stage tomato leaf miner larvae were placed individually on the leaves. Larval survival, total average male and female pupal weight and consumed foliar area were assessed for each genotype. It was determined that most wild species showed resistance to Tuta absoluta by antixenosis and antibiosis mechanisms. The genotype $S$. habrochaites (RCAT030597) presented more resistance by antibiosis based on larval survival. Nonetheless, the resistance-level characterization depended on the insect response that was considered because S. chilense was less preferred for oviposition; however, in this genotype, the larval survival in the no-choice assays was among the highest observed. Thus, this study provides comprehensive information on the resistance level of several Solanum genotypes that could be used in further efforts to understand the complex mechanisms underlying Solanum resistance to the tomato leaf miner.
\end{abstract}

Key words: Antibiosis, antixenosis, host plant resistance, insect-plant interactions, tomato.

\section{Introduction}

The tomato (Solanum lycopersicum L.) is the third most important horticultural crop in Chile

Received May 5, 2016. Accepted October 19, 2016. Corresponding author: rchorba@uc.cl and accounts for $30 \%$ of the global horticultural production, with approximately 4.7 million hectares cultivated and 159,347,030 tons harvested in 2011. The most important producers in South America are Brazil, Chile, Argentina and Colombia. Chile produced 872,485 tons in 2011, with 13,864 ha under production (FAOSTAT, 
2015). The expansion of areas under tomato cultivation has caused an increase in diseases and pests. Among the pests are the tomato leaf-miner Tuta absoluta (Meyrick); several species of aphids, particularly the green peach aphid, Myzus persicae (Sulzer), the melon aphid, Aphis gossypii (Glover), and the potato aphid, Macrosiphum euphorbiae (Thomas); the tomato russet mite, Aculops lycopersici (Massee); the western flower thrips, Frankliniella occidentalis (Pergande); the corn earworm, Heliothis zea (Boddie); and the greenhouse whitefly, Trialeurodes vaporariorum (Westwood) (Estay and Bruna, 2002; Álvarez, 2015).

Tuta absoluta is a Neotropical species that is considered a major pest in tomato production in South America (Guedes and Picanço, 2012; Luna et al., 2012). It has been one of the main tomato pests in many South American countries since the 1960s and, more recently, in Europe (Desneux et al., 2010). After its invasion of Europe in 2006, it has spread rapidly to the Mediterranean basin, Northern Africa and the Middle East (Desneux et al., 2011; Gharekhani and Salek-Ebrahimi, 2014). Tuta absoluta is considered a typical invasive species because of its capacity to develop rapidly on tomato crops and propagate rapidly in new areas, thereby causing significant economic losses (Desneux et al., 2010). Tuta absoluta is a multivoltine pest with a high reproductive potential and short life cycle (Pereyra and Sanchez, 2006). The adult female lays eggs, mostly singly, on leaves and stems. The young larvae develop inside the plant, and pupation occurs mainly in the soil. Larvae can damage tomato plants in all of their growth stages by producing galleries in leaves, stems, apical buds, and in green and ripe fruit, which result in significant losses in crop yields in different parts of the world and under diverse production systems (Lietti et al., 2005; Antônio et al., 2011).

Sources of natural resistance in wild and cultivated genotypes that provide protection from insect pests constitute an important contribution to integrated pest management. In general, the resistance mechanisms of plants against herbivorous insects can be divided into the categories of antixenosis and antibiosis. Antixenosis is defined as a response of the insect that results in a non-preference for plants that lack the necessary characteristics to serve as feeding, oviposition or refuge hosts (Painter, 1951). Antibiosis includes all adverse physiological effects of a temporary or permanent nature that occur in an insect as a result of ingesting a plant (Kogan, 1994). A considerable number of studies have described and investigated the resistance mechanisms of plants of the genus Solanum to disease-causing agents and insects (Kennedy, 2003); however, few studies have included Tuta absoluta. Hostplant resistance to tomato leaf miner has been reported for some host plants in the genus, such as Solanum pimpinellifolium, S. peruvianum, and $S$. habrochaites, compared with commercial tomato genotypes (Leite et al., 1995; Leite et al., 1999; Thomazini et al., 2001). A recent study demonstrated that genotypes that are produced with introgressions of the $T y-1$ gene from $S$. chilense to $S$. esculentum confer resistance to the tomato leaf miner (Duarte et al., 2015), thus demonstrating the utility of investigating genotypic resistance mechanisms.

Despite the general knowledge that wild relatives of the tomato are more resistant to the tomato leaf miner, we decided to characterize some of the genotypes conserved at the germplasms centers of Instituto de Investigaciones Agropecuarias (INIA) La Platina and INIA Vicuña to obtain a detailed biological response to this insect and to validate previous information. Hence, this research used a controlled methodology for artificial infestation by $T$. absoluta to assess the antixenosis and antibiosis resistance mechanisms in a comprehensive sample of the wild germplasm of Solanum section Lycopersicon and the commercial species Solanum lycopersicum. 


\section{Materials and methods}

\section{Assessed germplasm}

We evaluated three commonly used commercial genotypes of $S$. lycopersicum (Fiorentino, Naomi and Belle) (Bioamerica S.A.) and seven wild tomato genotypes: $S$. habrochaites (RCAT 030597, PI 126446), S. chilense (INIA BB79), Solanum peruvianum (RCAT 031296, RCAT 039874, RCAT 030403) and S. pimpinellifolium (PI 390739) (Germplasm Bank; INIA Vicuña, INIA La Platina). The wild genotypes show an indeterminate growth habit; therefore, the commercial genotypes were chosen to match this growth trait. The study was conducted at the $\mathrm{La}$ Platina Regional Research Center of the Instituto de Investigaciones Agropecuarias (INIA) located at $33^{\circ} 34^{\prime} \mathrm{S}$ and $70^{\circ} 38^{\prime} \mathrm{W}$ at 630 m.a.s.l.

The seeds were pre-germinated in petri plates (9 $\mathrm{cm}$ in diameter) on paper for subsequent inchamber germination (BTP $36 \mathrm{~L}$ 05, Phillips), at a temperature of $20 \pm 1^{\circ} \mathrm{C}$ and a photoperiod of $12 \mathrm{~h}$ light and $12 \mathrm{~h}$ darkness, until the radicle emerged, which was then transferred to seedling trays. The substrate used was composed by an 80:15:5 mixture of Canadian peat, horticultural vermiculite and dolomitic limestone. The seedling trays were kept in a polycarbonate greenhouse $\left(18 \mathrm{~m}^{2}\right)$ until two to four leaves appeared, at which point, they were transferred to pots. Nutrients were applied weekly from transplanting until the end of the assays. Modified Hoagland solutions composed of macronutrients $\left(\mathrm{KNO}_{3}, \mathrm{Ca}\left(\mathrm{NO}_{3}\right)_{2} \cdot 4 \mathrm{H}_{2} \mathrm{O}\right.$, $\left.\mathrm{NH}_{4} \mathrm{H}_{2} \mathrm{PO}_{4}, \mathrm{MgSO}_{4} .7 \mathrm{H}_{2} \mathrm{O}\right)$ and micronutrients $(\mathrm{KCl}$, $\mathrm{H}_{3} \mathrm{BO}_{3}, \mathrm{MnSO}_{4} \cdot \mathrm{H}_{2} \mathrm{O}, \mathrm{ZnSO}_{4} \cdot 7 \mathrm{H}_{2} \mathrm{O}, \mathrm{CuSO}_{4} \cdot 5 \mathrm{H}_{2} \mathrm{O}$, $\mathrm{H}_{2} \mathrm{MoO}_{4}\left(85 \% \mathrm{MoO}_{3}\right)$, Fe-chelate) were applied according to the nutritional requirements in the stage of plant development.

\section{Artificial rearing of Tuta absoluta}

Greenhouse-grown tomato plants of the commercial variety Linda were employed to rear the insects. The plants were infested with adult moths for breeding. Once the larvae were developed on the leaves, they were removed, transferred to the laboratory and kept in wide-mouthed glass flasks with water in transparent plastic chambers $(0.88 \times 0.78 \mathrm{~m})$ (Plas Labs, Inc. Model 830-CP21). The leaves were examined regularly until pupae appeared, and the latter were transferred to rearing chambers (BTP $36 \mathrm{~L}$ 05, Phillips) with a temperature maintained at below $9{ }^{\circ} \mathrm{C}$ until the antixenosis assay began. A separate subset of plants was maintained to rear a colony of T. absoluta, from which first-stage larvae were obtained for the antibiosis assays.

\section{Antixenosis bioassays}

There were 10 treatments in this experiment, each corresponding to a genotype of Solanum, with three replications and three observations per replication. One fully expanded leaf from the middle part of the plant was removed from each plant in all treatments. Each leaf was placed in a plastic cup containing a piece of floral foam (open-cell phenolic foam that absorbs water rapidly and is used as a base for cut flowers) that was soaked in water and a central opening that supported the leaf, with a tape attached to the petiole indicating the date, treatment and replication. The plastic cups were placed in $60 \times 40 \mathrm{~cm}$ exclusion cages in the greenhouse that were covered with anti-aphid mesh. Ten plastic cups were placed in each cage with leaves from all treatments, and a pair of adult tomato leaf miner moths (male and female) was released on each cage. The number of eggs per leaf of each genotype was counted. The variable studied was oviposition preference (\% of total eggs per female).

\section{Antibiosis bioassay}

There were 10 treatments in this experiment, each corresponding to a genotype of Solanum, with three replications and three observations per replication. 
One fully expanded leaf from the middle part of the plant of each genotype was detached and placed in a plastic cup with water. Each leaf was infested with one first-stage tomato leaf miner larva that was approximately 4 days old. The leaves were examined daily to determine whether there were larvae on them and to ensure that the water content of the cups was sufficient to keep the leaves hydrated. When the first larvae were observed to be approximating the pupal states, a small piece of cardboard was placed over the floral foam so the larvae would pupate on either the leaf or the cardboard. It was not necessary to change the leaves because the floral foam maintained sufficient moisture to keep the leaves hydrated throughout their development from larvae to pupae.

Larval survival was registered in percentages. Measurements of the total pupal weight and total male and female pupal weight (mg) were taken, and consumed foliar area was used as an indicator of damage using the Micrometrics SE Premium software (Standard Edition. 2000-2009), expressed in $\mathrm{cm}^{2}$.

\section{Statistical analyses}

A random block experimental design was used for both bioassays (antibiosis and antixenosis), with ten treatments and three replications. An ANOVA was applied to the dependent variables, followed by a means comparison test. A linear correlation analysis was used to determine the relationship between leaf area consumed and larval survival (PROC CORR). The statistical software program SAS/STAT 9.2 (SAS Institute Inc., Cary, NC, USA. 2010-2011) was used for the analyses.

\section{Results}

\section{Antixenosis bioassay}

The number of ovipositions per leaf was higher in the commercial genotypes of $S$. lycopersicum (cultivars Belle, Naomi and Fiorentino) than in the wild genotypes $\left(\mathrm{F}_{9,20}=33.02 ; \mathrm{P} \leq 0.001\right)$. Thus, commercial tomato genotypes received at least four times more eggs than did the least preferred genotypes. There were differences in female oviposition preference among the wild types, with accessions of S. peruvianum being more preferred than those of S. pimpinellifolium (PI390739) and $S$. chilense (INIABB79). The preference for $S$. habrochaites was more variable because $S$. habrochaites RCAT030597 received the same number of eggs as $S$. chilense did, whereas $S$. habrochaites PI126446 was at an intermediate level of preference within the wild types (Table 1).

Table 1. Effect of host genotype on oviposition preference of T. absoluta (Meyrick) in controlled oviposition choice experiments.

\begin{tabular}{lc}
\hline Genotype & Oviposition preference (\%) \\
\hline S. lycopersicum (Belle) & $19.72 \pm 0.78 \mathrm{a}$ \\
S. lycopersicum (Naomi) & $18.69 \pm 1.06 \mathrm{ab}$ \\
S. lycopersicum (Fiorentino) & $16.53 \pm 0.80 \mathrm{~b}$ \\
S. peruvianum (RCAT031296) & $9.12 \pm 1.55 \mathrm{c}$ \\
S. peruvianum (RCAT039874) & $8.40 \pm 1.19 \mathrm{c}$ \\
S. peruvianum (RCAT030403) & $7.93 \pm 1.56 \mathrm{c}$ \\
S. habrochaites (PI126446) & $6.33 \pm 1.22 \mathrm{~cd}$ \\
S. habrochaites & $4.62 \pm 0.26 \mathrm{~d}$ \\
(RCAT030597) & $4.62 \pm 0.66 \mathrm{~d}$ \\
S. chilense (INIABB79) & $4.04 \pm 0.63 \mathrm{~d}$ \\
S. pimpinellifolium (PI390739) & $\left(\mathrm{F}_{9,20}=33.02 ; \mathrm{P} \leq 0.001\right)$ \\
\hline
\end{tabular}

Treatment means followed by the same letter are not statically different (Fisher LSD, 0.05).

\section{Antibiosis bioassay}

Solanum genotypes had a large effect on larval survival, which ranged between 100 and $11 \%$, depending on the accession tested $\left(\mathrm{F}_{9,20}=9.33 ; \mathrm{P} \leq 0.001\right)$ (Table 2). The most susceptible cultivars were the commercial genotypes of $S$. lycopersicum (cultivars Fiorentino, Naomi and Belle) and the wild genotypes $S$. chilense (INIABB79) and S. habrochaites (PI126446), in which the larval survival was the highest. Larval survival was at an intermediate level on S. peruvianum (RCAT031296, RCAT030403, 
RCAT039874) and S. pimpinellifolium (PI390739), and it ranged between 55.5 and $72.3 \%$. The lowest larval survival rate of $11.1 \%$ was observed on $S$. habrochaites (RCAT030597) (Table 2).

Individual pupal weight was not as sensitive at detecting differences among genotypes as it was for larval survival. As expected, the total male pupal weight was lower than that of females. However, no differences were found among the different evaluated genotypes (Table 2). There was no register of total female pupae for the accession S. habrochaites (RCAT030597) because in this genotype only one male survived. Unfortunately, it is impossible to know if, by chance, all of the female larvae died or whether only males were randomly assigned to this treatment.

The amount of leaf area consumed by each $T$. absoluta larva varied depending on the Solanum genotype $\left(\mathrm{F}_{9,20}=2.46 ; \mathrm{P}=0.045\right)$ (Table 2). Larvae consumed more leaf area of $S$. lycopersicum (Fiorentino and Belle), but this consumption was not significantly different from those of S. lycopersicum (Naomi), S. pimpinellifolium (PI390739), S. peruvianum (RCAT030403) and S. chilense (INIABB79). In contrast, T. absoluta larvae consumed the least leaf area when fed on $S$. habrochaites (PI126446), which was significantly different from that of the commercial genotypes. The amount of leaf area consumed was positively correlated with larval survival $(\mathrm{r}=0.45 ; \mathrm{P}=0.013)$.

\section{Discussion}

Initially, antixenosis was termed non-preference by Painter (1951), who defined it as the response of insects to plants that lack the required characteristics to serve as hosts and is the result of negative reactions or total avoidance in the search for food, oviposition sites or refuge. Antixenosis has been reported in the genus Solanum Section lycopersicon and is associated with chemical compounds in the plant tissue (Smith, 2005; Neto et al., 2010). The antibiotic effect of a resistant plant can be lethal or produce chronic sub-lethal results that can arise from the chemical or morphological defense factors of the plant. The lethal effect can be acute, in which case, it often affects young larvae. Chronic antibiosis effects often result in slow growth or even mortality among older larvae. Insects that survive antibiosis to adulthood can suffer weakening effects of a smaller body size and weight, longer periods of development in immature stages and reduced fecundity (Suinaga et al., 2004; Schoonhoven et al., 2005; Smith, 2005).

This study compared the antixenosis and antibiosis effects of the wild species of Solanum ( $S$. habrochaites, $S$. chilense, $S$. peruvianum and $S$. pimpinellifolium) to those of commercial $S$. lycopersicum cultivars (Fiorentino, Naomi and Belle) on the response of T. absoluta, as evidenced by the differences among treatments. The greater susceptibility of cultivated tomato plants compared to wild genotypes was determined in relation to the expression of resistance, as evidenced by the differences in oviposition preference (antixenosis) and larval survival (antibiosis). This finding is interesting because other investigations have not found differences in oviposition preference (Boiça Junior et al., 2012). Differences were also determined between wild and commercial species in the total consumed foliar area by tomato leafminer larvae, with a greater damaged area observed in the commercial genotypes Fiorentino and Belle. Considering the larval survival among the wild genotypes, an intermediate resistance level was quantified on S. peruvianum, and greater resistance was measured on $S$. habrochaites. In accordance with this work, other reports have found higher resistance in wild genotypes compared with commercial cultivars (Thomazini et al., 2001; Proffit et al., 2011; Oliveira et al., 2012). Nonetheless, we here provide further information on the variability that can occur within a single genotype, depending on the accession tested, as we detected a wide range of larval survivals in the accessions of $S$. habrochaites (Table 2). Additionally, we demonstrated that the resistance level may vary depending on the insect response that is considered, as determined for $S$. chilense. In this genotype, 
Table 2. Average survival rate of T. absoluta larvae (Meyrick), average male and female pupal weight (mg) and consumed foliar area per leaf $\left(\mathrm{cm}^{2}\right)$ in the different laboratory treatments.

\begin{tabular}{lcccc}
\hline Genotype & Larval survival (\%) & $\begin{array}{c}\text { Leaf area consumed } \\
\left(\mathrm{cm}^{2} / \text { larva }\right)\end{array}$ & $\begin{array}{c}\text { Female pupal weight } \\
(\mathrm{mg})\end{array}$ & $\begin{array}{c}\text { Male pupal weight } \\
(\mathrm{mg})\end{array}$ \\
\hline S. lycopersicum (Naomi) & $100 \pm 0.0 \mathrm{a}$ & $19.83 \pm 2.5 \mathrm{ab}$ & $2.7 \pm 0.21$ & $1.6 \pm 0.05$ \\
S. lycopersicum (Fiorentino) & $100 \pm 0.0 \mathrm{a}$ & $24.23 \pm 2.5 \mathrm{a}$ & $2.8 \pm 0.10$ & $1.6 \pm 0.10$ \\
S. lycopersicum (Belle) & $100 \pm 0.0 \mathrm{a}$ & $23.27 \pm 3.0 \mathrm{a}$ & $2.9 \pm 0.20$ & $1.9 \pm 0.00$ \\
S. chilense (INIABB79) & $94.4 \pm 5.8 \mathrm{ab}$ & $15.43 \pm 2.4 \mathrm{abc}$ & $2.9 \pm 0.17$ & $1.6 \pm 0.06$ \\
S. habrochaites (PI126446) & $83.3 \pm 9.6 \mathrm{abc}$ & $10.47 \pm 0.6 \mathrm{c}$ & $2.7 \pm 0.22$ & $1.7 \pm 0.15$ \\
S. peruvianum (RCAT031296) & $72.3 \pm 5.5 \mathrm{bcd}$ & $13.13 \pm 1.1 \mathrm{bc}$ & $2.5 \pm 0.10$ & $1.7 \pm 0.09$ \\
S. peruvianum (RCAT030403) & $72.2 \pm 11.1 \mathrm{bcd}$ & $16.20 \pm 3.4 \mathrm{abc}$ & $2.6 \pm 0.05$ & $1.8 \pm 0.05$ \\
S. pimpinellifolium (PI390739) & $61.1 \pm 14.7 \mathrm{~cd}$ & $19.00 \pm 6.5 \mathrm{abc}$ & $2.7 \pm 0.12$ & $1.7 \pm 0.03$ \\
S. peruvianum (RCAT039874) & $55.5 \pm 14.7 \mathrm{~d}$ & $13.87 \pm 2.5 \mathrm{bc}$ & $2.9 \pm 0.35$ & $1.7 \pm 0.15$ \\
S. habrochaites (RCAT030597) & $11.1 \pm 11.1 \mathrm{e}$ & $11.83 \pm 0.7 \mathrm{bc}$ & $\mathrm{No} \mathrm{survivors}$ & $1.4 \pm 1$ \\
& $\left(\mathrm{~F}_{9,20}=9.33 ; \mathrm{P} \leq 0.001\right)$ & $\left(\mathrm{F}_{9,20}=2.46 ; \mathrm{P}=0.045\right)$ & $\left(\mathrm{F}_{8,18}=0.62 ; \mathrm{P}=0.750\right)$ & $\left(\mathrm{F}_{9,15}=1.44 ; \mathrm{P}=0.257\right)$ \\
\hline
\end{tabular}

${ }^{1} 1$ pupa.

Treatment means followed by the same letter in each column are not statically different (Fisher LSD, 0.05).

the female oviposition preference was the lowest, but it did not correlate with larval survival, which was among the highest. Thus, this study provides comprehensive information on the resistance level of several Solanum genotypes, which was assessed under controlled conditions of infestation with the tomato leaf miner.

This study provides evidence for further studies seeking to understand the proximal mechanisms underlying resistance expression to the tomato leaf miner, as chemical and/or physical plant traits could be related to plant resistance. Damage to the tomato plant is generally related to the level of secondary metabolites, which are toxic to insect pests. Consequently, secondary metabolites related to defense are stored in vacuoles and trichome heads. The secondary metabolites, such as methyl ketones, acylsugars, several phenolic compounds and sesquiterpenes, that are present in Solanum species could be related to the reduced insect survival and growth. Among them, 2-tridecanone and 2-undecanone methyl ketones have received special attention. Ecole et al. (1999) found that 2-tridecanone correlates with oviposition preference but not with larval performance, and Glas et al. (2012) reported that the susceptibility of $S$. lycopersicum is probably due to the absence of 2-tridecanone and 2-undecanone in type VI trichomes, although Chatzivasileiadis and Sabelis (1997) found both compounds in type VI trichome exudates of $S$. lycopersicum. One factor that may explain the presence of antixenosis and antibiosis in wild species is the presence and density of glandular trichomes. Simmons and Gurr (2005) noted that antibiosis is conferred by the chemical constituents of trichome exudates, although there is no consensus on this finding. During the domestication of the tomato, important alleles present in the gene pool of the genus were lost, resulting in a narrowing of its genetic base (Bai and Linhout, 2007). This may be one explanation for the susceptibility of commercial cultivars to insect pests. Current approaches to enhance plant resistance in commercial genotypes are looking to identify and transfer resistance-codifying genes into commercial lines, as demonstrated by the introgression of the Ty- 1 gene from $S$. chilense to $S$. esculentum (Duarte et al., 2015). Further studies could use the variability in larval and adult responses detected in this study to advance our knowledge on Solanum resistance traits to Tuta absoluta.

\section{Acknowledgments}

Wild Solanum seeds were provided by the germplasms centers of INIA La Platina and INIA Vicuña (Chile), and commercial genotypes by Bioamerica S.A. 


\title{
Resumen
}

\begin{abstract}
N. Vitta, P. Estay y Chorbadjian, R.A. 2016. Caracterización de la expresión de resistencia en genotipos de Solanum Sección Lycopersicon contra Tuta absoluta (Lepidoptera: Gelechiidae). Cien. Inv. Agr. 43(3):366-373. Se condujeron dos estudios para caracterizar los mecanismos de resistencia por antixenosis y antibiosis de genotipos de Solanum sección Lycopersicon a Tuta absoluta (Meyrick). Las especies utilizadas fueron Solanum lycopersicum (Fiorentino, Naomi y Belle), S. habrochaites (RCAT030597, PI126446), S. chilense (INIABB79), S. peruvianum (RCAT031296, RCAT039874, RCAT030403) y S. pimpinellifolium (PI390739). Para la evaluación de antixenosis, se retiró una hoja de cada planta y se colocó en un recipiente con espuma floral embebida en agua. Los recipientes se introdujeron en jaulas cubiertas de malla anti-áfidos. Se determinó el número de huevos por planta a los siete días después de la liberación de los adultos. Similarmente, pero en forma independiente, cada hoja se inoculó con una larva de primer estado, evaluándose su sobrevivencia, peso final de pupas hembras y machos y el área foliar consumida. Se determinó que la mayoría de los genotipos silvestres expresaron mecanismos de resistencia a Tuta absoluta por antixenosis y/o antibiosis. El genotipo S. habrochaites (RCAT030597) presentó mayor resistencia por antibiosis basado en la sobrevivencia de las larvas y daño foliar. No obstante, la caracterización del nivel de resistencia dependió de la respuesta considerada, ya que $S$. chilense fue menos preferido para oviposición pero en este genotipo la sobrevivencia de las larvas estuvo entre las más altas. Así, este estudio proporciona información adicional del nivel de resistencia de varios genotipos de Solanum, la que podría ser utilizada en futuros esfuerzos para comprender los complejos mecanismos que subyacen la expresión de resistencia de Solanum a la polilla del tomate.
\end{abstract}

Palabras clave: Antibiosis, antixenosis, interacciones insecto-planta, resistencia de hospedero, tomate.

\section{References}

Álvarez, M. 2015. Insect resistance in tomato (Solanum spp.). Cultivos Tropicales 36: 100-110.

Antônio, A.C., D.J.H. Silva, M.C. Picanço, N.T. Santos, and M.E.S. Fernandes. 2011. Tomato plant inheritance of antixenotic resistance to tomato leafminer. Pesq. Agropec. Bras. 46: 74-80.

Bai, Y., and P. Lindhout. 2007. Domestication and breeding of tomatoes: What have we gained and what can we gain in the future? Ann. Bot. 100: 1085-1094.

Boiça Junior, A. L., D.B. Bottega, A.L. Lourenção, and N.E.L. Rodrigues. 2012. Não preferência para oviposição e alimentação por Tuta absoluta (Meyrick) em genótipos de tomateiro Arq. Inst. Biol. 79:541-548.

Chatzivasileiadis, E.A., and M.W. Sabelis. 1997. Toxicity of methyl ketones from tomato trichomes to Tetranychus urticae Koch. Exp. Appl. Acarol. 21: 473-484.
Desneux, N., E. Wajnberg, K.A.G. Wyckhuys, G. Burgio, S. Arpaia, C.A. Narváez-Vasquez, J. González -Cabrera, D.C. Ruescas, E. Tabone, J. Frandon, J. Pizzol, C. Poncet, T. Cabello, and A. Urbaneja. 2010. Biological invasion of European tomato crops by Tuta absoluta: ecology, history of invasion and prospects for biological control. J. Pest Sci. 83: 197-215.

Desneux, N., M.G. Luna, T. Guillemaud, and A. Urbaneja. 2011. The invasive South American tomato pinworm, Tuta absoluta, continues to spread in Afro-Eurasia and beyond: the new threat to tomato world production. J. Pest Sci. 84: 403-408.

Duarte, L., M. A. Martínez, and V. H. P. Bueno. 2015. Biology and population parameters of Tuta $a b-$ soluta (Meyrick) under laboratory conditions. Rev. Protección Veg. 30: 19-29.

Ecole, C.C., M. Picanço, G.N. Jham, and R.N.C. Guedes. 1999. Variability of Lycopersicon hirsutum f. typicum and possible compound involved 
in its resistance to Tuta absoluta. Agr. Forest Entomol. 1: 249-254.

Estay, P., and A. Bruna. 2002. Insectos y ácaros asociados al tomate en Chile. Colección Libros INIA $\mathrm{N}^{\circ}$ 7. Santiago, Chile. $111 \mathrm{pp}$.

FAOSTAT. 2015. Food and Agriculture Organization of the United Nations. Available at online: http://faostat.fao.org/site/567/DesktopDefault. aspx?PageID=567\#ancor (Website accessed: November, 2015).

Gharekhani, G.H., and H. Salek-Ebrahimi. 2014. Life table parameters of Tuta absoluta (Lepidoptera: Gelechiidae) on different varieties of Tomato. J. Econ. Entomol. 107: 1765-1770.

Glas, J.J., B.C.J. Schimmel, J.M. Alba, R. EscobarBravo, R.C. Schuurink, and M.R. Kant. 2012. Plant glandular trichomes as targets for breeding or engineering of resistance to herbivores. Int. J. Mol. Sci. 13: 17077-17103.

Guedes, R.N.C., and M.C. Picanço. 2012. The tomato borer Tuta absoluta in South America: pest status, management and insecticide resistance. EPPO Bulletin 42: 211-216.

Kennedy, G. G. 2003. Tomato, pests, parasitoids, and predators: Tritrophic interactions involving the genus Lycopersicon. Annu. Rev. Entomol. 48: 51-72.

Kogan, M. 1994. Ecological Aspects of Pest Management. In: Metcalf, R., and W.H. Luckmann (eds.). Introduction to Insect Pest Management. 3rd Edition. Canada. United States. 672 pp.

Leite, G. L. D., M. Picanço, A. A. Azevedo, and A. H. R. Gonring. 1999. Efeito de tricomas, aleloquímicos e nutrientes na resistência de Lycopersicon hirsutum à traça-do-tomateiro. Pesq. Agropec. Bras. 34: 2059-2064.

Leite, G.L.D., M. Picanço, D.J.H. Silva, A.C. Mata, and G.N. Jham. 1995. Distribuiçâo de oviposiçâo de Scrobipalpuloides absoluta no dossel de Lycopersicon esculentum, L. hirsutum e L. peruvianum. Hortic. Bras. 13: 47-51.

Lietti, M.M.M., E. Botto, and R.A. Alzogaray. 2005. Insecticide Resistance in Argentine Populations of Tuta absoluta (Meyrick) (Lepidoptera: Gelechiidae). Neotrop. Entomol. 34: 113-119.
Luna, M. G., N. E. Sanchez, P. C. Pereyra, E. Nieves, V. Savino, E. Luft, E. Virla, and S. Speranza. 2012. Biological control of Tuta absoluta in Argentina and Italy: evaluation of indigenous insects as natural enemies. EPPO Bulletin 42: 260-267.

Neto A.C.G., V.F. Silva, W.R. Maluf, G.M. Maciel, D.A.C. Nízio, L.A.A. Gomes, and S.M. Azevedo. 2010. Resistência à traça-do-tomateiro em plantas com altos teores de acilaçúcares nas folhas. Hortic. Bras. 28: 203-208.

Oliveira, C.M., V.C.Jr. Andrade, W.R. Maluf, I.P. Neiva, and G.M. Maciel. 2012. Resistance of tomato strains to the moth Tuta absoluta, imparted by allelochemicals and trichome density. Ciênc. Agrotec. 36: 45-52.

Painter, R. 1951. Insect resistance in crop plants. The Macmillan Co., New York.

Pereyra, P.C., and N.E. Sanchez. 2006. Effect of two solanaceous plants on developmental and population parameters of the tomato leaf miner, Tuta absoluta (Meyrick) (Lepidoptera: Gelechiidae). Neotrop. Entomol. 35: 671-676.

Proffit, M., G. Birgersson, M. Bengtsson, R.Jr. Reis, P. Witzgall, P., and E. Lima. 2011. Attraction and oviposition of Tuta absoluta females in response to tomato leaf volatiles. J. Chem. Ecol. 37: 565-574.

Schoonhoven, L.M., J.J.A. van Loon, and M. Dicke. 2005. Insect-Plant Biology. Second edition. Oxford University Press.

Simmons, A.T., and G.M. Gurr. 2005. Trichomes of $L y$ copersicon species and their hybrids: effects on pests and natural enemies. Agr. Forest Entomol. 8: 1-11.

Smith, C.M. 2005. Plant resistance to arthropods. Molecular and Conventional Approaches. Springer, Dordrecht, Netherlands.

Suinaga, F.A., M.C. Picanço, M.D. Moreira, A.A. Semeão, S.T.V. Magalhães. 2004. Resistência por antibiose de Lycopersicon peruvianum à traça do tomateiro. Hortic. Bras. 22: 281-285.

Thomazini A.P.B.W., J.D. Vendramim, R. Brunherotto, M.T.R. Lopes. 2001. Efeito de Genótipos de Tomateiro sobre a Biologia e Oviposição de Tuta absoluta (Meyrick) (Lep.: Gelechiidae). Neotrop. Entomol. 30:283-288. 